\title{
Urgency of Resilience and Optimism in Improving Students' Mental Health
}

(Urgensi Resiliensi dan Optimisme dalam Mengembangkan Kesehatan Mental Mahasiswa)

\author{
Retno Mangestuti*, Yulia Sholichatun, Rahmat Aziz, Esa Nur Wahyuni \\ Department of Psychology, Faculty of Psychology, Universitas Islam Negeri Maulana Malik Ibrahim Malang, \\ Gajayana Street No.50, Malang, East Java, 65144 Indonesia \\ *corresponding author, e-mail: mangestuti@uin-malang.ac.id
}

Article received: April $17^{\text {th }} 2020$; revised: July $5^{\text {th }} 2020$; accepted: August $25^{\text {th }} 2020$

\begin{abstract}
Mental health study has become an intriguing and vital carried out by various experts according to their scientific discipline. This study aims to test the role of optimism as a mediator for the relationship of resilience with students' mental health. The subjects were 320 students in four state Islamic colleges in East Java, Indonesia. Data obtained through the mental health scale, resilience scale, and optimism scale. Data were analyzed using regression analysis techniques. The analysis shows that the resilience has direct effects of 1.398 ( $\mathrm{p}$ bigger than 0.01 ) and indirect effects of 0.312 (p bigger than 0.01 ) through optimism on students' mental health. The implication of this result is the importance of resilience and optimism aspects to be considered in developing students' mental health. Resilience will be more effective if the individual has a high level of optimism. Thus, to develop students' mental health, these two abilities needed to be accelerated.
\end{abstract}

Keywords: mental health; resilience; optimism

\begin{abstract}
Abstrak: Kesehatan mental menjadi suatu kajian yang menarik dan penting sehingga banyak dilakukan oleh berbagai ahli sesuai dengan disiplin keilmuannya. Penelitian ini bertujuan untuk menguji peran optimisme sebagai mediator pada hubungan antara resiliensi dan kesehatan mental. Subjek penelitian sebanyak 320 mahasiswa yang diambil secara acak dengan mempertimbangkan komposisi jumlah di empat Perguruan Tinggi Keagamaan Islam Negeri yang ada di Jawa Timur, Indonesia. Data diperoleh melalui skala kesehatan mental, skala resiliensi, dan skala optimisme. Data dianalisis dengan menggunakan teknik analisis regresi. Hasil analisis menunjukkan bahwa resiliensi berpengaruh secara langsung sebesar 1,398 ( $\mathrm{p}$ lebih besar dari 0,01) dan tidak langsung sebesar 0,312 (p lebih besar dari $0,01)$ melalui optimisme terhadap kesehatan mental mahasiswa. Implikasi dari hasil penelitian ini adalah pentingnya aspek resiliensi, dan optimisme untuk diperhatikan dalam upaya pengembangan kesehatan mental mahasiswa. Resiliensi akan lebih efektif berpengaruh jika individu memiliki tingkat optimisme yang tinggi, sehingga untuk mengembangkan kesehatan mental pada mahasiswa perlu mengembangkan dua kemampuan tersebut.
\end{abstract}

Kata kunci: kesehatan mental; resiliensi; optimisme 


\section{INTRODUCTION}

In the guidance and counseling context, mental health becomes a strategic and essential issue to be considered due to the significantly increasing social and emotional problems faced by college students. It is confirmed from the tremendous mental health problems that emerged from students' relation and counselors' vital role in establishing students' mental health, as well as the enhanced academic success from the institution in accelerating its students' mental health (Cowie et al., 2004). Their huge academic task, the study routine in their courses, high demand for thinking critically, and the request to contribute to society living can transform into academic stressors (Hicks \& Heastie, 2008). That stressor generates a mental health crisis that leads to lower academic achievement. Thus, counselors have a significant role in developing college students' mental health.

In psychology theoretical review, mental health is frequently defined as the absence of mental illness, such as anxiety, depression, and losing control of someones' behavior. Recently, mental health has been translated into both negative and positive patterns. In a positive pattern, it is defined as someone's ability to attain positive situations, such as feeling happy, loved, and life satisfaction. This approach is based on the presumption that someone's positive and negative conditions do not always contradict each other. They may exist at the same time.

The studies on the positive aspect of mental health, which is also popular as psychological wellbeing, have been massively carried out. One of the monumental studies on this topic focuses on the relation between physical and mental health (Bartels, 2015). Another research reveals that mental health can predict longevity (Steptoe et al., 2008). Besides, several other studies also discover an exceptionally closed relation between mental health and the improvement of physical fitness, happiness, the meaning of life, longevity, successful career, social connection, and cognitive function (Kirkcaldy, 2015).

Many factors are presumed to affect the level of students' mental health, both internal or external. As mentioned in one research, the external factor explains that mental health is affected by the place where someone is living (Rees et al., 2015). Meanwhile, in the internal aspect, as identified in one study, resilience substantially influences the level of mental health (Marchand et al., 2015). Resilience is someone's success in adapting to a full of pressure situations. An individual with remarkable resilience tends to have excellent mental health. Some personal characteristics that affect the resilience process have a role in the healthy consequence after a stressful event ends (Zautra et al., 2005).

The resilience term was first introduced by Block (Klohnen, 1996), who defines it as the general ability involving the flexible adaptation skills whenever faced with internal and external pressure. Unlike that definition, Rutter (2007) uses the resilience term to illustrate the children with excellent functions even when they have a dreadful family environment full of pressures. Besides, Remirez (2007) pictures three indicators related to individual resilience. First, effective coping depicts someone with the ability to resolve difficulties with practical means. Second, the mastery that displays someone's comprehensive knowledge and skill. Lastly, the positive adaptation represents someone's ability to get back from difficulties in their lives.

In addition to the resilience factor, optimism is also essential to mental health. It is someone's hope that everything works smoothly in a positive way. Optimism is defined as someone's hope for a positive experience (Bressler et al., 2010). It leads people to obtain their purpose. Optimism turns people to opt-out of problems quickly, due to their mind, feel, and ability (Snyder \& Lopez, 2002). Studies on the relation of optimism and adverse mental health have been carried out. The results confirm that individuals with optimism traits tend to have a lower stress level (Calandri et al., 2016). Some studies report the relation between optimism and students' stress. The freshman students possess high optimism; they exhibited substantial welfare, which transformed into psychological stress three months later. In other words, optimism carries direct and indirect welfare through the adaptive coping method (Krypel \& Henderson-King, 2010).

This study investigates the direct and indirect effects of internal factors of resilience and optimism on college students' mental health, with optimism as the mediator variable. Those two variables were chosen based on the presumption that students have both skills and potential to be developed at the university level. 


\section{METHOD}

This research uses the quantitative method. The research population was all students in Islamic States Universities in East Java, Indonesia, while the subjects were 320 randomly chosen students, considering the balance of the Universities. This study was conducted in four universities of Universitas Islam Negeri Maulana Malik Ibrahim Malang, Universitas Islam Negeri Sunan Ampel Surabaya, Institut Agama Islam Negeri Jember, and Institut Agama Islam Negeri Tulungagung. The complete participants' data are presented in Table 1.

The data collection process was carried out with three measuring instruments. The mental health measurement was completed using The 12-item General Mental Health Questionnaire (12-GMHQ) developed by Goldberg and Hilliear (1979). This instrument reveals the general mental health and has been used in various countries with high reliability and validity values (Fellinger et al., 2005; Kihc et al., 1997). In Indonesia, this 12-GMHQ has been evaluated in many research and can be recommended as a screening instrument in different health facilities (Primasari \& Hidayat, 2016). Simultaneously, the resilience was measured using an instrument developed by Remirez (2007). This instrument demonstrates three indicators, namely: effective coping, mastery, and positive adaptation. That instrument has been utilized in many research, including those conducted in Indonesia. Meanwhile, the optimism was measured using the Revised Life Orientation Scale (LOT-R) arranged by Scheier, Carver, \& Bridges, (1994). It consists of ten question items in a Likert Scale form. The three items evaluate optimism, three items measure pessimism, and four essay items with no score. This instrument is the revision version of the Life Orientation Scale (LOT) and has been implemented in many studies with excellent validity and reliability score (Kiling et al., 2019).

The data were analyzed through the mediated regression technique. The PROCESS program, recommended by Hayes (2013), was used in the analysis process. Hayes recommended bootstrapping to estimate the indefinite indirect effect, similar to the one experienced by the Sobel test and the causal effect model. This program also facilitates analysis output in the form of indirect effect $(a * b)$, including confidence interval and effect size.

Table 1. Composition of Research Participant

\begin{tabular}{lcccccc}
\hline \multicolumn{1}{c}{ University Name } & \multicolumn{2}{c}{ Male } & \multicolumn{2}{c}{ Female } & \multicolumn{2}{c}{ Total } \\
& F & $\mathbf{\%}$ & F & \% & F & \% \\
\hline Universitas Islam Negeri Maulana Malik Ibrahim Malang & 15 & 4.69 & 65 & 20.31 & 80 & 25 \\
Universitas Islam Negeri Sunan Ampel Surabaya & 28 & 8.75 & 52 & 16.25 & 80 & 25 \\
Institut Agama Islam Negeri Jember & 24 & 7.50 & 56 & 17.50 & 80 & 25 \\
Institut Agama Islam Negeri Tulungagung & 59 & 18.44 & 21 & 6.56 & 80 & 25 \\
Total & 126 & 39.38 & 194 & 60.63 & 320 & 100 \\
\hline
\end{tabular}

\section{RESULTS}

The regression analysis results in the effects of resilience and optimism toward mental health show an $\mathrm{R}=0.645$ score with a determinant coefficient of $\mathrm{R}=0.416$. After the adjusted $\mathrm{R}$ squared, it transforms to be 0.413 . It shows that the optimism and resilience variable can be the predictors of the students' mental health of $41.3 \%$. It indicates the presence of other factors that affect $58.7 \%$ of students' mental health. Meanwhile, the regression analysis results on the simultaneous effects of resilience and optimism on the students' mental health reveal $\mathrm{R}=0.665$. The determinant coefficient of $\mathrm{R}=0.442$, after the adjusted R, squared it changes to 0.437 . It shows that the resilience and optimism variable can be the $41.3 \%$ predictor of students' mental health level. Thus, higher resilience and optimism indicate the students' mental health. Additionally, the results of resilience effect on mental health show $\beta=0.474$ $(p<0.010)$ correlation, while the impact of optimism toward mental health shows a correlation of $\beta=0.283$ $(\mathrm{p}<0.010)$, as presented in Table 2 .

In addition, the evaluation of the indirect effects of resilience toward mental health through optimism was completed using the PROCESS procedure through several stages. The results of that analysis show that the resilience effect $(\mathrm{X})$ on optimism $(\mathrm{M})$ has a path coefficient of 0.312 and a significant $\mathrm{p}<0.01$ level. Meanwhile, the impact of optimism (M) on mental health (Y) owns a b path coefficient of 0.639 
Table 2. The Results of Correlation Analysis

\begin{tabular}{lccc}
\hline Variable & B & P & Description \\
\hline Resilience & 0.474 & $<0.010$ & Significant \\
Optimism & 0.283 & $<0.010$ & Significant \\
\hline
\end{tabular}

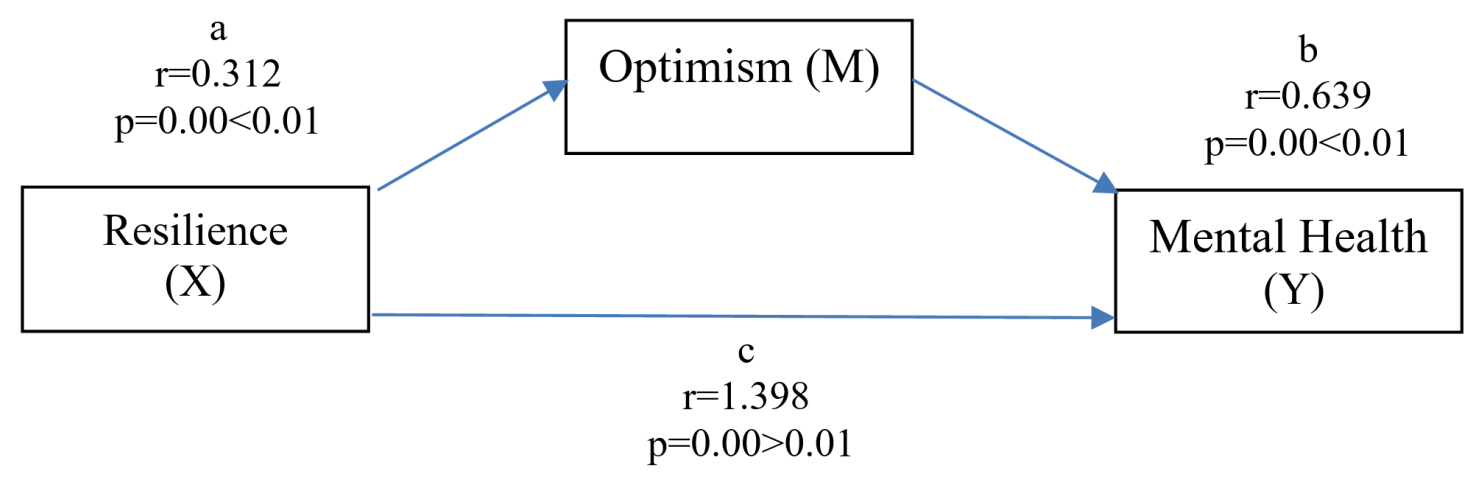

Figure 1. The Analysis Results of Resilience's Indirect Effect toward Mental Health through Optimism

and significant at $\mathrm{p}<0.01$ level. Besides, the direct effect of resilience toward mental health $(\mathrm{Y})$ or the immediate effect of $\mathrm{X}$ to $\mathrm{Y}$ has a c coefficient path of 1.398 and significant toward $\mathrm{p}<0.01$ level. The indirect effect of resilience $(\mathrm{X})$ to mental health $(\mathrm{Y})\left(\mathrm{a}^{*} \mathrm{~b}\right)$ is 0.199 (c' path). Since the significant a and $\mathrm{b}$ path, according to Baron and Kenny (1986), the mediation role emerges. In other words, optimism can be the mediator variable on the relationship between resilience and college students' mental health, as illustrated in Figure 1.

The investigation of resilience's indirect effects on mental health through optimism was carried out through several stages. Linear to the recommendation of Baron and Kenny (1986), the first stage analysis is carried out by the regression analysis to test the accomplishment of the three required conditions. The first condition is to test the independent variable (resilience) as the essential predictor toward the dependent variable (mental health). The results of that analysis identify $t(204)=-2.04 ; p<0.05$ score. The second condition is to evaluate the independent variable (resilience) as the significant predictor toward the mediator variable (optimism). Its results show $\mathrm{t}(204)=-4.86 ; \mathrm{p}<0.01$ score. The third condition is to examine the role of the independent variable (resilience) and mediator variable (optimism) in predicting the dependent variable (mental health). That examination results in $t$ value of $(203)=-0.397 ; p>0.05$. The insignificant $\mathrm{p}$-value demonstrates that the standard regression coefficient between resilience and mental health reduces following the control on optimism. The results of data analysis reveal the relationship between resilience and mental health mediated by optimism.

\section{DISCUSSION}

The analysis results on the indirect influences of resilience to mental health through optimism, showing that optimism can be the mediator variable in relation to those variables. This result is linear to the research results conducted by Souri and Hasanirad (2011) on medical students. That study result confirms that resilience predicts psychological welfare, as one of the mental health aspects, while optimism plays a mediator role concerning those two variables.

Several studies on optimism as the mediator variable have been massively conducted. One of the research reveals that optimism can be the mediator or intermediary on the relation between religiosity variables and the subject's life quality (Calandri et al., 2016). Different studies observe the relation among religiosity and spirituality variables with subjects' depression, the relation of their trust to the world with the subjects' welfare (Jiang et al., 2016), and optimism as a mediator on the relationship between violence experience and children's psychological pressure (Brodhagen \& Wise, 2008).

Further, Souri and Hasanirad (2011) explain the possible interactive relation of resilience and optimism. Resilience affects the emergence of optimism and vice versa. It is consistent with the finding of previous research that reveals the relationships among those variables (Scheier et al., 2001). In other words, individuals with excellent resilience levels tend to have high optimism and vice versa. Further 
research also shows that optimism is the contributing factor toward resilience (Gómez- Molinero et al., 2018). It is identified as the most influential cognitive factor in teenagers' lower life pressure effects (Tusaie \& Dyer, 2004). Essentially, optimism reflects an individual's positive behaviour toward difficult situations, so it is placed as an essential component of resilience. Similarly, the previous research has confirmed the relation of positive optimism to well-being. Meanwhile, resilience as a vital component of psychological welfare is also consistent with previous research results (Souri \& Hasanirad, 2011).

The research result demonstrates that resilience possibly has roots in religious and cultural values. It is considerably related to optimistic behavior. In Indonesia, religious society, represented explicitly by the characteristics of students from four Islamic State Universities in East Java, has placed optimism as one of the mental behaviors guided by the religions. Consequently, religious belief can be the primary element of optimism. A spiritual person believes that life has meaning, even in his most severe condition. They have resilience since they are optimistic that all issues can be solved. As explained by Rutter (2007), that resilience illustrates the optimism in facing pressure. Thus, optimism follows resilience during a stressful situation (Carver, Scheir, \& Segerstrom, 2010). Stress is one of the adverse effects on mental health (Veit \& Ware, 1983). Consequently, optimism has a crucial role in someone's adaptation process toward a stressful situation. In facing a challenge, optimist individuals are observed to be more steadfast, even when the situation gets tougher (Snyder \& Lopez, 2002). Optimism seems to be the variable that depicts individual differences, reflecting someones' ability to maintain their future hopes (Scheier et al., 2001).

Optimism is one of the variables correlated to psychological welfare that leads to consciousness of social integrity, including the spiritual life elements (Souri \& Hasanirad, 2011). This is in accordance with a previous study on the positive connection between belief and emotional prosperity on Christians (Tix et al., 2013), along with a survey of belief and positive emotion of Muslims, which also involves their optimism (Tiliouine \& Estes, 2016). Another possible mechanism among aspects of belief, including optimism, positive emotion, and well-being, is the presence of belief to fulfill the lifting needs and desires, involving social support, social connection, self-transcendence, self-concept, sense of control, and sense of meaning. People can also use their beliefs to attain meaning from their life's pressure or difficulties. During the difficult situation, people can feel that The Almighty protects them and that their suffering is part of the more substantial plan to get connected to God (Miller-Perrin \& Krumrei Mancuso, 2015).

This research results affect universities' educational practices, and that education is one of the strategies to develop students; mental health. It can be implemented through guidance and counseling practices that recognize students' resilience and optimism aspects as a potential to be developed. The solvency of students' issues does not always come in a practical solution but also appears in counselors' skills to help students comprehend and build their resilience and optimism. Consequently, students attain a positive effect that they have the ability to solve problems they currently encounter.

Many different approaches can be implemented in the guidance and counseling service to teach and develop students' resilience and optimism. One of those approaches is Cognitive Behavior Modification $(\mathrm{CBM})$, introduced by Meichenbaum. It is an intervention with a cognitive perspective. Some studies have tested its effectiveness in improving positive emotion and solve the emotional problem (Wahyuni, 2017) in connection to resilience (Barbosa, 2020; Hidayati et al., 2020; Naeem et al., 2020; Beadel et al., 2016) and optimism (Golby \& Wood, 2016). According to Wahyuni (2012), The use of CBM in enhancing positive emotion and behavior, such as resilience and optimism, can be selected based on some considerations. First, emotion (optimism and resilience) is the result of someone's perception and assessment of a situation they encountered. CBM is an approach that emphasizes the cognitive function in evaluating an accident or stimulus that generates emotion. CBM concept relies on someone's cognitive that holds a significant role in the development and management of reaction, as well as behaviors toward a situation through a cognitive process, such as creating meaning, evaluation and assumption. Second, CBM accentuates self-learning therapy, so that counselees are conscious of their mind, which has been directed toward themselves. The therapy process allows the individual to transform his learning method so that they get to be more independent in facing their issues. Students' independence in solving their problems is the embodiment of resilience level. Further, resilience presents the feeling that they are capable of solving issues (optimism). This condition aids students in adapting and maintaining their emotional stability as an indicator of someone with a healthy mind. 


\section{CONCLUSION}

The research results confirm that resilience is a variable that directly affects students' mental health and indirect effect on students' mental health through optimism. In other words, resilience brings a more substantial impact on individuals with excellent optimism levels. Students' mental health development can be carried out through the establishment of resilience. Its practical implication on university education is the understanding and realization of education as one of the strategic means in developing their students' mental health. This development is way more effective if started from the development of optimism and resilience.

\section{REFERENCES}

Barbosa, G. (2020). Psychotherapy in one Approach of Resilience (PAR). Pratiques Basées Sur La Résilience, 115.

Baron, R. M., \& Kenny, D. A. (1986). The moderator-mediator variable distinction in social psychological research: Conceptual, strategic, and statistical considerations. Journal of Personality and Social Psychology, 51(6), 1173-1182.

Bartels, M. (2015). Genetics of wellbeing and its components satisfaction with life, happiness, and quality of life: A review and meta-analysis of heritability studies. Behavior Genetics, 45(2), 137-156. https://doi.org/10.1007/ s10519-015-9713-y

Beadel, J. R., Mathews, A., \& Teachman, B. A. (2016). Cognitive bias modification to enhance resilience to a panic challenge. Cognitive Therapy and Research, 40(6), 799-812.

Bressler, L. A., Bressler, M. E., \& Bressler, M. S. (2010). The role and relationship of hope, optimism and goal setting in achieving academic success: A study of students enrolled in online accounting courses. Academy of Educational Leadership Journal, 14(4), 38-51.

Brodhagen, A., \& Wise, D. (2008). Optimism as a mediator between the experience of child abuse, other traumatic events, and distress. Journal of Family Violence, 23(6), 403-411. https://doi.org/10.1007/s10896-008-9165-8

Calandri, E., Graziano, F., Borghi, M., \& Bonino, S. (2018). Depression, positive and negative affect, optimism and health-related quality of life in recently diagnosed multiple sclerosis patients: The role of identity, sense of coherence, and self-efficacy. Journal of Happiness Studies, 19(1), 277-295. https://doi.org/10.1007/s10902016-9818-x

Carver, C. S., Scheier, M. F., \& Segerstrom, S. C. (2010). Optimism. Clinical psychology review, 30(7), 879-889.

Cheadle, A. C., \& Schetter, C. D. (2018). Mastery, self-esteem, and optimism mediate the link between religiousness and spirituality and postpartum depression. Journal of Behavioral Medicine, 41(5), 711-721. https://doi. org/10.1007/s10865-018-9941-8

Cowie, H., Boardman, C., Dawkins, J., \& Jennifer, D. (2004). Emotional health and well-being: A Practical guide for schools. SAGE Publications.

Fellinger, J., Holzinger, D., Dobner, U., Gerich, J., Lehner, R., Lenz, G., \& Goldberg, D. (2005). Mental distress and quality of life in a deaf population. Social Psychiatry and Psychiatric Epidemiology, 40(9), 737-742. https://doi.org/10.1007/s00127-005-0936-8

Golby, J., \& Wood, P. (2016). The effects of psychological skills training on mental toughness and psychological well-being of student-athletes. Psychology, 7(06), 901-913.

Goldberg, D. P., \& Hillier, V. F. (1979). A scaled version of the General Health Questionnaire. Psychological Medicine, 9(1), 139-145. https://doi.org/10.1017/S0033291700021644

Gómez- Molinero, R., Zayas, A., Ruíz-González, P., \& Guil, R. (2018). Optimism and resilience among university students. International Journal of Developmental and Educational Psychology. Revista INFAD de Psicología., 1(1), 147-153. https://doi.org/10.17060/ijodaep.2018.n1.v1.1179

Hicks, T., \& Heastie, S. (2008). High school to college transition: A profile of the stressors, physical and psychological health issues that affect the first-year on-campus college student. Faculty Working Papers from the School of Education, 14, 1-6.

Hidayati, R., Hidayah, N., Ramli, M., Hambali, I., \& Triyono, T. (2020). Efektifitas cognitive behaviour therapy di sekolah: Meta analisis review. Biblio Couns: Jurnal Kajian Konseling dan Pendidikan, 3(1), 31-40.

Jiang, F., Yue, X., Lu, S., Yu, G., \& Zhu, F. (2016). How belief in a just world benefits mental health: The effects of optimism and gratitude. Social Indicators Research, 126(1), 411-423. https://doi.org/10.1007/s11205-0150877-x 
Kihc, C., Rezaki, M., Rezaki, B., Kaplan, I., Ozgen, G., Sagduyu, A., \& Ozturk, M. O. (1997). General Health Questionnaire (GHQ12 \& GHQ28): Psychometric properties and factor structure of the scales in a Turkish primary care sample. Social Psychiatry and Psychiatric Epidemiology, 32(6), 327-331. https://doi. org/10.1007/BF00805437

Kiling, I. Y., Manafe, Y. M., \& Bunga, B. N. (2019). Optimisme disposisional dan pengukurannya pada orang usia lanjut. Journal of Health and Behavioral Science, 1(1), 1-12.

Kirkcaldy, B. (Ed.). (2015). Promoting Psychological Well-being in Children and Families. Palgrave Macmillan. https://doi.org/10.1057/9781137479969

Klohnen, E. C. (1996). Conceptual analysis and measurement of the construct of ego-resiliency. Journal of Personality and Social Psychology, 70(5), 1067-1079.

Krypel, M. N., \& Henderson-King, D. (2010). Stress, coping styles, and optimism: Are they related to meaning of education in students' lives? Social Psychology of Education, 13(3), 409-424. https://doi.org/10.1007/ s11218-010-9132-0

Marchand, A., Durand, P., Haines, V., \& Harvey, S. (2015). The multilevel determinants of workers' mental health: Results from the SALVEO study. Social Psychiatry and Psychiatric Epidemiology, 50(3), 445-459. https:// doi.org/10.1007/s00127-014-0932-y

Miller-Perrin, C., \& Krumrei Mancuso, E. (2015). Faith from a positive psychology perspective. Springer Netherlands. http://link.springer.com/10.1007/978-94-017-9436-7

Naeem, F., Irfan, M., \& Javed, A. (2020). Coping with Covid-19: urgent need for building resilience through cognitive behaviour therapy. Khyber Medical University Journal, 12(1), 1-3.

Primasari, I., \& Hidayat, R. (2016). General Health Qquestionnaire-12 (GHQ-12) sebagai Instrumen Skrinning Gangguan Penyesuaian. Jurnal Psikologi, 43(2), 121-134.

Rees, C. S., Breen, L. J., Cusack, L., \& Hegney, D. (2015). Understanding individual resilience in the workplace: The international collaboration of workforce resilience model. Frontiers in Psychology, 6, 73. https://doi. org/10.3389/fpsyg.2015.00073

Remirez, M. E. (2007). Resilience: A concept analysis. Nursing Forum, 42(2), 122-135. https://doi.org/10.1111/ j.1744-6198.2007.00070.x

Rutter, M. (2007). Resilience, competence, and coping. Child Abuse \& Neglect, 31(3), 205-209. https://doi. org/10.1016/j.chiabu.2007.02.001

Scheier, M. F., Carver, C. S., \& Bridges, M. W. (1994). Distinguishing optimism from neuroticism (and trait anxiety, self-mastery, and self-esteem): A reevaluation of the Life Orientation Test. Journal of Personality and Social Psychology, 67(6), 1063.

Scheier, M. F., Carver, C. S., \& Bridges, M. W. (2001). Optimism, pessimism, and psychological well-being. Optimism and Pessimism: Implications for Theory, Research, and Practice, 1, 189-216.

Snyder, C. R., \& Lopez, S. J. (Eds.). (2002). Handbook of positive psychology. Oxford University Press.

Souri, H., \& Hasanirad, T. (2011). Relationship between resilience, optimism and psychological well-being in students of medicine. Procedia-Social and Behavioral Sciences, 30, 1541-1544.

Steptoe, A., O'Donnell, K., Marmot, M., \& Wardle, J. (2008). Positive affect and psychosocial processes related to health. British Journal of Psychology, 99(2), 211-227. https://doi.org/10.1111/j.2044-8295.2008.tb00474.x

Tiliouine, H., \& Estes, R. J. (Eds.). (2016). The state of social progress of Islamic societies. Springer International Publishing. http://link.springer.com/10.1007/978-3-319-24774-8

Tix, A. P., Johnson, M. E., Dik, B. J., \& Steger, M. F. (2013). Religious commitment and subjective well-being across Christian traditions. Journal of Psychology \& Christianity, 32(1), 20-29.

Tusaie, K., \& Dyer, J. (2004). Resilience: A historical review of the construct. Holistic Nursing Practice, 18(1), 3-10. https://doi.org/10.1097/00004650-200401000-00002

Veit, C. T., \& Ware, J. E. (1983). The structure of psychological distress and well-being in general populations. Journal of Consulting and Clinical Psychology, 51(5), 730-742.

Wahyuni, E. N. (2012). Keefektifan pendekatan cognitive behavior modification untuk meningkatkan kemampuan mengelola marah bagi remaja [Unpublished doctoral dissertation]. Universitas Negeri Malang

Wahyuni, E. N. (2017). Mengelola stres dengan pendekatan cognitive behavior modification (studi eksperimen pada mahasiswa baru pendidikan agama islam (PAI) Fakultas Ilmu Tarbiyah \& Keguruan UIN Maliki Malang). Tadrib, 3(1), 98-117. 
Zautra, A. J., Johnson, L. M., \& Davis, M. C. (2005). Positive affect as a source of resilience for women in chronic pain. Journal of Consulting and Clinical Psychology, 73(2), 212-220. https://doi.org/10.1037/0022006X.73.2.212 